\title{
CULTURAL HERITAGE CONSERVATION AND CULTURE-LED TOURISM CONFLICT WITHIN THE HISTORIC SITE IN BEYOĞLU, ISTANBUL
}

\author{
ADEM ERDEM ERBAS \\ Mimar Sinan Fine Arts University, Faculty of Architecture, \\ City and Regional Planning Department, Turkey
}

\begin{abstract}
In the metropolitan city of Istanbul, the conservation of historic sites that are under the influence of tourism pressure is one of the central challenges of management planning. This study aims to perform a critical review, within the framework of the current conservation legislation of Turkey and ICOMOS decisions, of the conservation master plan prepared for Beyoğlu (Istanbul), particularly focusing on conflicts between cultural heritage conservation and culture-led tourism decisions. The review starts out with an analysis of Beyoğlu district in Istanbul, based on the technical expertise reports drawn from the administrative court decisions, followed by a discussion of the results. The study includes four main parts, with the first part discussing and then conceptualizing the cultural heritage conservation and culture-led tourism, the second part examining the definition of the conservation site and the conservation master plan process, the third part addressing the analysis and evaluation of the site within the context of cultural heritage, and the final part discussing the findings and drawing conclusions. Some of the findings derived from the evaluations conducted on the Beyoğlu conservation master plan are given: (a) due to the lack of a holistic planning approach, the conservation master plan boundaries fail to incorporate other historic areas in the same district; (b) the decision to reconstruct former historic buildings damages the present use of public space; (c) car-oriented transport designs increase vehicle traffic in the historic centre of the city; and (d) the existing cultural structure is undergoing "touristification" in the form of culture-led tourism development, and cultural functions are being rapidly "commercialized". The results of the study show that the Beyoğlu (Istanbul) conservation master plan produces negative effects on the tangible and intangible heritage, publicness, public participation, culture-led tourism, and culture-led urban regeneration.
\end{abstract}

Keywords: cultural heritage conservation, tangible and intangible heritage culture-led tourism, conservation master plan.

\section{INTRODUCTION}

Tourism functions as one of largest economic sectors for countries. Over recent years, there has been rapid growth observed in international tourism activities, thanks primarily to the increased amount of leisure time in societies, improvements in the quality of life, increased accessibility to transport, especially airline travel, rise in socio-economic development level, improved socio-political conditions, and advances in communications technology and broad network-access digital technologies, like smartphones and social media platforms [1].

One of the dilemmas that emerge from the increase in tourism activity is how to provide a healthy balance between the influx of visitors to cultural heritage areas and the preservation of the well-being of the host communities, in terms of privacy, cultural values and norms, and quality of life. Concerning the socio-cultural structure, the failure to involve the local host community in the planning and development process may lead to negative consequences for tourism activities, such as "zoo syndrome" [1]. Within the framework of neoliberal policies, a close relationship exists between the transformation of cultural heritage areas into predominantly consumer spaces and the "touristification" and "commercialization" of these areas [1]-[6]. This issue takes on even greater importance 
within the context of the development dynamics of large-scale metropolitan cities. Central business district activities on the metropolitan scale produce major pressure on the built-up environment of the historical centre [7]. Cultural heritage areas are under the influence of both metropolitan development dynamics and the development pressure of tourism movements. The tourism pressure placed on the historical environment that is required to be conserved is among the primary issues for management planning.

The restrictions on the participation of local community in planning and decisionmaking processes can create potential conflicts in the land-use decisions and the use of common public areas during and after the process [8]. Therefore, it is necessary to pay attention to the interests, concerns, and opinion of the local community during the planning and decision-making stages for cultural heritage areas. National and international cultural tourism movements can lead to increased potential for conflicts over the cultural consumption of space in terms of local sensitivities. This has been particularly true when it comes to historical-environmental conservation and cultural heritage conservation, where the conflicts over the cultural consumption of place have had a major impact on tangible and intangible heritage conservation practices. Depending on the management method applied to govern tourism activities, the tangible heritage may be either a threat or an opportunity for the "intangible heritage" [1], [9], [10], which includes not only the civil architecture and monumental structures, but also the richness of knowledge and skill transferred from one generation to another. In other words, the definition and meaning of cultural heritage does not involve only monuments, collections, and objects [9], [10]. Today, the intangible cultural heritage list prepared by UNESCO includes 470 different elements from 117 countries [10]. In the representative List of the Intangible Cultural Heritage of Humanity, the intangible cultural heritage elements from Turkey include the following: Mevlevi Sema ceremony, Arts of the Meddah, public storytellers (2008), Karagöz, Âşıklık (minstrelsy) tradition (2009), Traditional Sohbet meetings, Semah, AleviBektaşi ritual, Kırkpınar oil wrestling festival (2010), Ceremonial Keşkek tradition (2011), Mesir Macunu festival (2012), Turkish coffee culture and tradition (2013), Ebru (Turkish art of marbling) (2014), Traditional craftsmanship of Çini-making, Nevruz, Yufka (2016), Spring celebration, Hidrellez, and Whistled language (2017).

Evaluating cultural heritage in these terms, conservation planning approaches in cultural heritage areas are expected to be respectful to the social and cultural values belonging to social memory, such as literature, traditions, beliefs, and legends, the performing arts, such as traditional music, dance and theatre, the social events, such as rituals, carnivals, and festivals, and the knowledge and skills for traditional production. This study aims to perform a critical review of the conservation master plan prepared for Beyoğlu (Istanbul) within the scope of current conservation legislation and ICOMOS decisions. This critical review includes an examination of the conflicts between cultural heritage conservation and culture-led tourism [11], [12]. The review starts out with an analysis of Beyoğlu district in Istanbul, based on the technical expertise reports drawn from the administrative court decisions, followed by a discussion of the results. The study is arranged in four main parts, starting with the introduction, where the cultural heritage conservation and culture-led tourism are discussed and then conceptualized. The second part examines the definition of the Istanbul Beyoğlu conservation site and conservation master plan process; the third part evaluates the site within the context of cultural heritage conservation; and the final part discusses the findings and draws conclusions. 


\section{ISTANBUL BEYOĞLU CONSERVATION SITE AND CONSERVATION MASTER PLAN}

The Beyoğlu settlement features many cultural, social, economic, and historical elements that are considered valuable, not only to Istanbul but also to the national and international community, on account of its deep-rooted history, the relics of which testify to its innovative and leading position in society; the settlement is unique in this respect. The location and socio-economic characteristics of the settlement, which has been shaped over time by life itself, have many important reference points to be considered concerning conservation, use, and development within the context of the conditions specific to "identity", "belonging" and "location".

Located within the borders of Beyoğlu at the entrance to the Historical Peninsula, Beyoğlu and Haliç (the Golden Horn), the neighbourhood of Galata was originally a Genoese trade colony of major importance. The Galata Tower, which was built in the 6th century $\mathrm{AD}$, stood outside the city walls of Constantinople. After the 11th century, merchants from Venice, Genoa, and Pisa, whose companies were engaged in sea trade on the Mediterranean, gradually began to dominate the unsettled coasts of Byzantium. These city-state built structures in Galata and its surrounding vicinity, soon transforming this region into a trade centre. It was especially the Venetians and Genoese who played a crucial role in orchestrating trade in this region. As can be observed in the Ottoman miniature art created by Matrakçı Nasuh in the first half of the 16th century, Galata Tower and its surroundings, as well as the area outside the walls of Galata, were located among vineyards and orchards, where only a few buildings were present. As a result of the Ottoman Empire's policy of establishing permanent embassies between countries, which started with the establishment of the French embassy in 1535, was the first embassy building built by the French played a significant role in the development of the region. After the other embassies had settled in the region in the 17th and 18th centuries, the district began to become an important area for foreign nationals and non-Muslim minorities, as well as for embassy officials. In addition to the palaces that were built along with the embassies, other buildings, such as magnificent houses, hotels for hosting foreign travellers and guests, post offices, and telegraph offices, greatly contributed to the development of the region. Moreover, many important examples of Westernization, like theatres, coffee houses, pastry shops, shopping arcades, inns, stores, printing houses, and newspaper bureaus, were concentrated in this region. Much of the great wealth that the region attracted was clustered on what is today Istiklal Avenue, and the streets attached to it [13]-[15]. The addition of the newest transportation systems - especially in the 19th century - like tramlines and tunnels linking the two sides of Istanbul, significantly affected the development of Beyoğlu. During its most prosperous period, in the 19th century, the "Levantines", who constituted a considerable part of the cosmopolitan life in Istanbul, also began to settle in the Beyoğlu region. Apart from the social structure and spatial development, Beyoğlu features very important "port city" characteristics. The construction of numerous structures commissioned by the Ottoman Navy (shipyards, cannonball moulding structures, etc.), as well as docks and warehouses to meet maritime trade needs, helped to build up other functions of the region that relied on the development of the port. It is important that evaluations of the port and the port functions defining the settlement character be based on their integration with the interior parts of the settlement and their interaction with each other. It is quite clear that the Bosporus and Haliç region, which constitute the waterfront sections of Beyoğlu, hosts a valuable "port heritage". The development of trade in Beyoğlu and the settlement of embassies in the region led to the construction of religious structures, like churches, synagogues, and mosques, and the settlement of minorities who used them, 


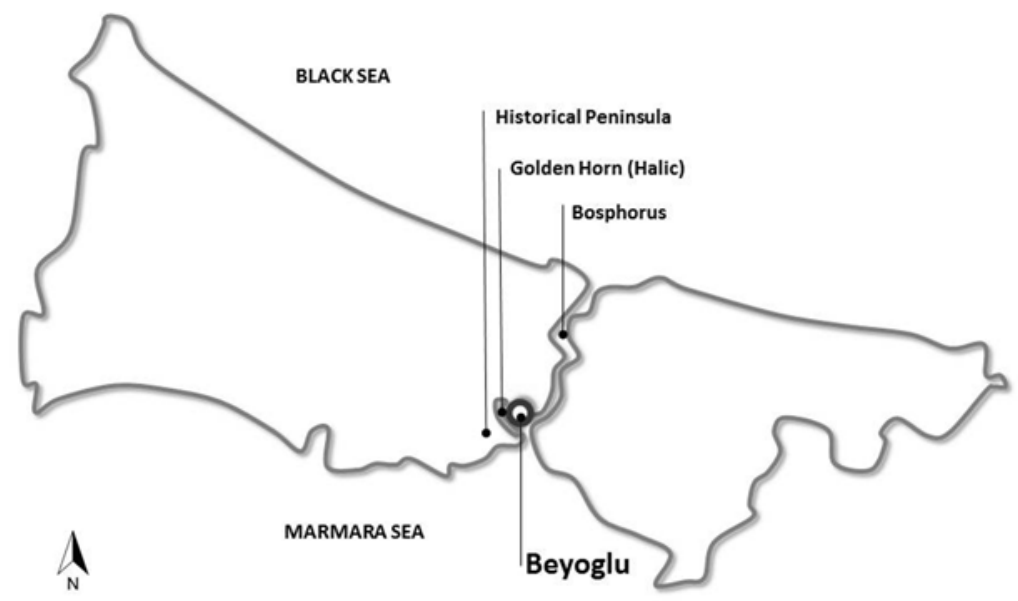

Figure 1: Beyoğlu District Municipality in Istanbul. (Source: by Author.)

such as Greeks, Armenians, and Jews. With the further development of trade areas in Galata, traders and bankers generally had their homes built in the Beyoğlu region, as it offered a culturally rich environment with its inns, shopping arcades, schools, cultural centres, theatres and concert halls. In addition to the religious structures, Beyoğlu featured many of the finest structures and service establishments to be found in the Ottoman Empire, many of which were the first of their kind, such as the embassy buildings, theatres, municipality facilities, hotels, restaurants, cafes, taverns, shopping arcades, and modern houses. The settlements of Galata and Beyoğlu were the first to be built with masonry, as a response to the fires that had ravaged Istanbul and destroyed many of the wooden structures. With these accomplishments, Beyoğlu can be considered as a city of "firsts" [15].

The multi-layer urban texture formed by the developments explained above forms the basis of the tangible and intangible heritage in Beyoğlu. The Beyoğlu Urban Site, which includes this heritage site, was registered with the decision no. 4720 dated 07.07 .1993 of the Istanbul Cultural and Natural Heritage Conservation Board No 1. The works for a 1/5000 scale Conservation Master Plan for the Beyoğlu Urban Site were initiated for the region, with temporary settlement conditions defined with the decision no. 4954, dated 29.09.1993 of the Istanbul Cultural and Natural Heritage Conservation Board No 1. Within the context of these decisions, the 1/1000 scale Beyoğlu Urban Site Conservation Implementation Plan and the 1/5000 scale Beyoğlu Urban Site Conservation Master Plan, were prepared and sent to the district conservation plan committee. Revisions, amendments, and additions were made to the conservation master plans with the decisions no. 1254, dated 19.09.2007 and no. 2302, dated 07.01.2009 by the Istanbul Cultural and Natural Heritage Conservation Board No II. Following these revisions, amendments, and additions, the 1/5000 scale Beyoğlu Urban Site Conservation Master Plan was approved in 2009, and the 1/1000 scale Beyoğlu Urban Site Conservation Implementation Plan was approved in 2011. After the approval of the plans, non-governmental organizations, chamber of planners and architects, and residents made appeals against the policies, and high judicial cases were opened. These cases are still ongoing. Today, Beyoğlu covers an area of 
approximately 830 ha, but the planning area of the Beyoğlu Urban Site, which is the study subject, is 320 ha and covers approximately $39 \%$ of the district area [15].

\section{CHALLENGES FOR THE BEYOĞLU CONSERVATION MASTER PLAN IN \\ THE CONTEXT OF CULTURAL HERITAGE AND CULTURE-LED TOURISM}

In the plan boundaries specified by the $1 / 5000$ and $1 / 1000$ scale conservation master plans, which are the subject of this study on Beyoğlu District, the plan population is indicated to be approximately 100.000 in plan reports. Accordingly, on the basis of the specified population according to the land determination presented in the plan for Beyoğlu, an increase of approximately 10.000 in population is expected. However, compared to the 2010 plan, there is no increase expected in employment opportunities, and it has been determined that the number of existing employment opportunities is two times that of the population dwelling within the planning area. In analysing the reports related to the Urban Site and Implementation Conservation Master Plan, it was seen that the "Beyoğlu Urban Site Field Work Zones" are divided into five zones, each having their own distinct features. These zones are designated as Galata-Karaköy-Tünel and its surroundings, Istiklal StreetÇukurcuma-Tophane and its surroundings, Cihangir-Gümüşsuyu-Taksim Square and its surroundings, Talimhane-Tarlabaşı and its surroundings, and Haliç Shipyard and its surroundings. The Perşembe Bazaar and Galata Port and Dock regions, which are within close proximity to Beyoğlu, extend beyond the plan boundaries in the analysis and synthesis works, as well as in the planning works.

As a result, there are no synthesis works regarding the interaction between the aforementioned regions and the planning area that is subject to the plan reports. The plan decisions to be produced in these regions that have been excluded from the Beyoğlu conservation master plan process will, however, inevitably affect all of Beyoğlu. With the new passenger port and related facilities in the Galata region, there will be substantial landuse changes in the Beyoğlu conservation master plan. Moreover, the fact that the projects being undertaken by other waterfront regions, like the Perşembe Bazaar and Haliçport, are considered separate, that is, in isolation from the Beyoğlu conservation master plan, damages the integrity of the plans and creates fragmentation in the planning process. In addition, regarding the Beyoğlu conservation master plan decisions, there are serious conflicts concerning the conservation of cultural heritage between stakeholders, especially about Taksim Square and Gezi Park. The issues and related conflicts, along with a map of the areas under dispute, are presented in Table 1 and Fig. 2.

For the decision-making process of the Beyoğlu Conservation Master Plan, evaluations should be conducted in terms of cultural heritage and culture-led tourism.

Physical aging: This pertains strictly to the quality of the structure, and the studies related to physical aging involve examination of building type and building status and analysis of function. In plan reports, the evaluation of physical aging was explained as, "The evaluation within the scope of building status was made considering visual and aesthetic values but not technical and static values". In this sense, physical aging was examined in terms of visual and aesthetic values, which involve subjectivity and different perspectives based on personal opinions, but it did not rely on any kind of technical measurements.

Social aging: There is no analysis regarding the determination of social aging in the plan report and therefore, it is not clear which factors are used to determine social aging. However, in the report, there are explanations about social aging, which are specified 
Table 1: Important issues creating conflict for the cultural heritage conservation of the Beyoğlu Urban Site and its surroundings. (Source: Adapted from IBB 2008 by Author.)

\begin{tabular}{|c|c|}
\hline No/location/issue & Conflicts related to cultural heritage conservation \\
\hline $\begin{array}{l}\text { (1) Azapkapı: } \\
\text { The construction of Metro } \\
\text { Bridge-Haliç crossing. }\end{array}$ & $\begin{array}{l}\text { The effect of the tower height of the Metro Bridge on the } \\
\text { historical silhouette of the old city; demolition of the } \\
\text { historic fabric. }\end{array}$ \\
\hline $\begin{array}{l}\text { (2) Perşembe Pazarı: } \\
\text { Failure to be included } \\
\text { within the borders of the } \\
\text { Beyoğlu Conservation Plan }\end{array}$ & $\begin{array}{l}\text { The use of the harbour area of the old Genoese settlement } \\
\text { in a manner that compromises the general spirit of } \\
\text { Beyoglu district; } \\
\text { Fragmented planning concept. }\end{array}$ \\
\hline $\begin{array}{l}\text { (3) Galata Tower and its } \\
\text { Surroundings: } \\
\text { Failure to be included } \\
\text { within the borders of the } \\
\text { Beyoğlu Conservation Plan }\end{array}$ & $\begin{array}{l}\text { Tourism-oriented redevelopment decisions on the Galata } \\
\text { Tower and its surroundings, which belong to the old } \\
\text { Genoese settlement that will compromise the general } \\
\text { spirit of Beyoğlu district; } \\
\text { Fragmented planning concept. }\end{array}$ \\
\hline $\begin{array}{l}\text { (4) Şişhane-Kasımpaşa: } \\
\text { Transformation of Haliç } \\
\text { Shipyard }\end{array}$ & $\begin{array}{l}\text { The transformation of the Ottoman Empire's "port } \\
\text { heritage" area into new functions, such as the Science } \\
\text { Centre, which does not reflect this heritage (The other two } \\
\text { shipyard areas in Haliç were previously privatized under } \\
\text { the "Haliçport" project site). }\end{array}$ \\
\hline $\begin{array}{l}\text { (5) Asmalımescit: } \\
\text { Narmanlı Han restoration }\end{array}$ & $\begin{array}{l}\text { The effect of the applied project on the original } \\
\text { architectural values of the Han. }\end{array}$ \\
\hline $\begin{array}{l}\text { (6) Tepebaşi: } \\
\text { Transformation to tourism } \\
\text { and accommodation } \\
\text { function }\end{array}$ & $\begin{array}{l}\text { The transformation of the Palazzo Corpi building, which } \\
\text { belongs to a former Genoese banking family (Corpi) and } \\
\text { has served as the American Consulate, to a hotel, once the } \\
\text { relocation of the consulate is decided upon; change of } \\
\text { ownership of buildings like Pera Palas Hotel; speculative } \\
\text { projects for the existing multi-storey parking area in the } \\
\text { area where the Old Tepebaş1 Theatre is present. }\end{array}$ \\
\hline $\begin{array}{l}\text { (7) Istiklal Avenue: } \\
\text { Grand Pera shopping } \\
\text { centre }\end{array}$ & $\begin{array}{l}\text { The transformation of the Cercle d'Orient building, built } \\
\text { in } 1882 \text { by the famous architect Alexandre Vallaury and } \\
\text { functioning as an iconic structure in Istanbul, into a } \\
\text { shopping centre; the effect that the restoration work on the } \\
\text { old building would have on the original architectural } \\
\text { values of the building; transformation of the old Emek } \\
\text { (the famous Melek Cinema of the period), one of the } \\
\text { symbols of the city, into a movie theatre to be located } \\
\text { within a shopping centre, }\end{array}$ \\
\hline $\begin{array}{l}8 \text { Istiklal Avenue: } \\
\text { Demirören shopping centre }\end{array}$ & $\begin{array}{l}\text { In place of the traditional shopping arcades present in } \\
\text { Beyoğlu, a new shopping centre, one reflecting the traces } \\
\text { of the modern city, is being considered. }\end{array}$ \\
\hline $\begin{array}{l}\text { (9) Tarlabaşı: } \\
\text { The announcement of } \\
\text { Tarlabaşı historical } \\
\text { residential area as a } \\
\text { renovation area }\end{array}$ & $\begin{array}{l}\text { The potential gentrification caused by the urban } \\
\text { transformation project in the old residential area of } \\
\text { Tarlabaş1; } \\
\text { The effect of the destruction and reconstruction of the } \\
\text { historic fabric on the original architectural values. }\end{array}$ \\
\hline
\end{tabular}


Table 1: Continued.

\begin{tabular}{|c|c|}
\hline No/location/issue & Conflicts related to cultural heritage conservation \\
\hline $\begin{array}{l}\text { (10) Taksim: } \\
\text { Mosque project for Taksim } \\
\text { Square }\end{array}$ & $\begin{array}{l}\text { The implementation of the project, which has been at the } \\
\text { centre of a long political debate, on the agenda of the city. }\end{array}$ \\
\hline $\begin{array}{l}\text { (11) Taksim: } \\
\text { Taksim Square traffic } \\
\text { tunnel project and } \\
\text { reconstruction of the old } \\
\text { Topçu Kışlası (reclamation } \\
\text { decision) }\end{array}$ & $\begin{array}{l}\text { Redirecting the traffic in Taksim Square underground; } \\
\text { increased traffic problem in the region due to vehicle } \\
\text { priority intersection applications; the plan to reconstruct } \\
\text { the barracks building in the existing "Gezi Park", which is } \\
\text { part of the plaza and the large social protests against this } \\
\text { project. }\end{array}$ \\
\hline $\begin{array}{l}\text { 12) Taksim Siraselviler: } \\
\text { Majik Cinema (Maksim } \\
\text { Casino, Taksim Stage) - } \\
\text { Hotel Project }\end{array}$ & $\begin{array}{l}\text { The transformation of the building, which had been built } \\
\text { by Italian architect Giulio Mongeri in } 1914 \text { and opened as } \\
\text { Majik Cinema, into a tourism and accommodation } \\
\text { function. }\end{array}$ \\
\hline $\begin{array}{l}13 \text { Taksim: } \\
\text { Atatürk Culture Centre }\end{array}$ & $\begin{array}{l}\text { The decisions to let Atatürk Cultural Centre, whose } \\
\text { symbolic presence has been part of the collective memory } \\
\text { of the city since 1969, remain non-functional for a long } \\
\text { period of time, the results of which led to its eventual } \\
\text { destruction in 2018; the intention to embark on a New } \\
\text { Ataturk Culture Centre project, one that will include a } \\
\text { high architectural concept, opera, ballet, theatre and } \\
\text { eating and drinking functions. }\end{array}$ \\
\hline $\begin{array}{l}\text { 14) Taksim Siraselviler: } \\
\text { The destruction and } \\
\text { reconstruction of Taksim } \\
\text { Ilkyardım Hospital }\end{array}$ & $\begin{array}{l}\text { The relocation of the hospital building, which functions } \\
\text { within an urban service area, after its destruction, and the } \\
\text { importance of protecting the housing fabric of the } \\
\text { historical area; the reconstruction of the hospital at its } \\
\text { current site. }\end{array}$ \\
\hline $\begin{array}{l}\text { (15) Cihangir: } \\
\text { The construction of a car } \\
\text { parking area under } \\
\text { Cihangir Park }\end{array}$ & $\begin{array}{l}\text { The plan to design one of the rare green spaces in the } \\
\text { housing fabric of the historical environment as a car } \\
\text { parking area; constructing the car parking area } \\
\text { underground to protect the green area; implementation of } \\
\text { private vehicle priority transportation policies and the } \\
\text { potential threat this poses to maintaining the integrity of } \\
\text { the historical fabric. }\end{array}$ \\
\hline $\begin{array}{l}\text { (16) Taksim Gümüşsuyu: } \\
\text { Park Hotel construction }\end{array}$ & $\begin{array}{l}\text { The projected height of the massive new hotel being built } \\
\text { at the former site of the Park Hotel, a structure that stands } \\
\text { as an icon in the collective memory of the city, and its } \\
\text { impact on the historical skyline (floors added at a later } \\
\text { time were destroyed); } \\
\text { The failure to include the Park Hotel area, declared to be a } \\
\text { tourism area, within the Beyoğlu Conservation Plan } \\
\text { borders. }\end{array}$ \\
\hline $\begin{array}{l}\text { (17) Kabataş: } \\
\text { Kabataş transportation } \\
\text { transfer centre }\end{array}$ & $\begin{array}{l}\text { The effects that the transportation transfer centre decision } \\
\text { applied to the waterfront area of Beyoglu will have on the } \\
\text { land prices in the nearby neighbourhoods and on the } \\
\text { transformation of the housing function. }\end{array}$ \\
\hline
\end{tabular}


Table 1: Continued.

\begin{tabular}{|l|l|}
\hline No/location/issue & Conflicts related to cultural heritage conservation \\
\hline (18) Salipazarı: & $\begin{array}{l}\text { The effects that the development cruise port project for } \\
\text { the old Galata Dock and its immediate vicinity will have } \\
\text { on land prices in the immediate vicinity and on the } \\
\text { transformation of the housing function; the opening of } \\
\text { many hotels in the vicinity as a result of the project; the } \\
\text { development of shopping malls and hotels to serve the } \\
\text { city as part of the cruise port project; the privatization of } \\
\text { the Galataport Project and the potential threat it poses to } \\
\text { compromising the general spirit of the Beyoğlu district; } \\
\text { Fragmented planning concept. }\end{array}$ \\
\hline $\begin{array}{l}\text { 19) Tophane: } \\
\text { Reclamation of Imalat-1 }\end{array}$ & $\begin{array}{l}\text { The reconstruction project of the Ottoman military } \\
\text { structure and its impact on the multi-layered urban fabric } \\
\text { that hosts the archaeological finds of the early Byzantine } \\
\text { period. }\end{array}$ \\
\hline $\begin{array}{l}\text { (20) Tophane Karaköy: } \\
\text { Transformation of } \\
\text { traditional urban fabric } \\
\text { into tourism, } \\
\text { accommodation, trade, } \\
\text { shopping, café, eating and } \\
\text { drinking venues, }\end{array}$ & $\begin{array}{l}\text { The transformation of the traditional urban fabric in the } \\
\text { Karaköy region into tourism, accommodation, trade, } \\
\text { shopping, café, eating and drinking establishments as a } \\
\text { result of the influence of other projects in the region, } \\
\text { especially the Galataport Project, } \\
\text { The gentrification effect of the projects in the region. }\end{array}$ \\
\hline
\end{tabular}

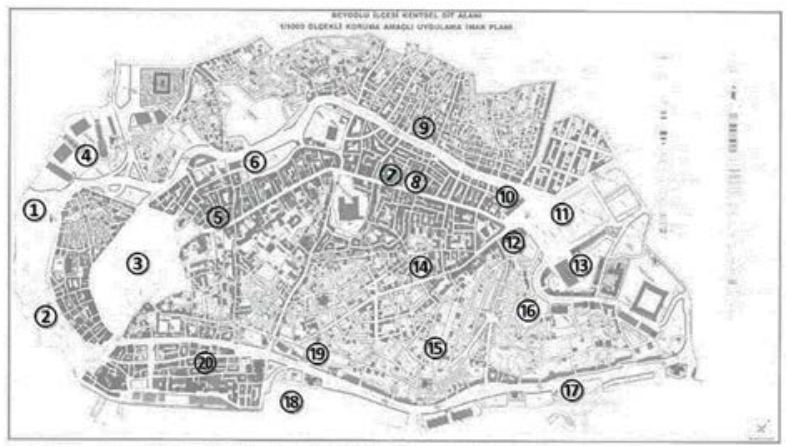

Figure 2: The locations corresponding to the important issues creating conflicts for the cultural heritage conservation of the Beyoğlu Urban Site and its surroundings. (Source: Adapted from IBB 2008 by Author.)

below, and in these explanations, social aging appears to be based on stratum, marginal groups, east and southeast migration, and the existence of bachelors. In researching social aging, it is important to specify the areas wherein the social economic and politic structure and the spatial data coincide. Hence, studies that are conducted by social science experts help to orientate spatial plan decisions to be taken for an area that needs conservation. However, the urban transformation being prepared as part of the Beyoğlu Conservation 
Master Plan is being justified on the basis of social aging, without conducting any kind of social structure study; the social aging aspect is therefore technically insufficient.

Destruction of historic fabric: In the plan report, the idea of destruction of historic fabric is addressed in terms of almost all types of factors, with a general explanation being provided and measurable values being given as rate and number.

Day and night population: The low night population in city centres is a general problem, one that is the inevitable result of the very specific hours of operation and population capacity of the existing functions. According to contemporary planning theories, a low night population can be attributed to an insecure night environment, as compared to the day environment. However, it cannot be said that every place with a low night population is necessarily derelict, with a low environmental quality. This generalization is not appropriate. Improving spatial quality with measures such as 24-hour usage of urban space and increasing the number of urban public areas, as well as open and green areas, will serve only to improve the physical space quality. In the plan report, there is no framework for the social structure at user level. This aforementioned deterministic perspective is based on the fact that an improvement in spatial quality alone will change only the social structure. The conservation master plan largely focuses on quality improvement to physical space.

Brownfield redevelopment: Very important urban projects are generally carried out to refunction old industrial areas, ports, shipyards, and the like, which have been separated from the industrial city and have lost much of their functionality. However, the evaluation of the existing status of Haliç Shipyard structures, in terms of renewal stemming from their aging, shows that this area housing these structures is not being considered as a potential area for waterfront urban public space. Moreover, it is an unacceptable view that a unique shipyard area - presented in the plan report as having an existing industrial heritage causes "visual pollution".

Urban transportation decisions: The Beyoğlu urban site is a transition hub for urban transportation. Increased transit traffic from the First Bosporus Bridge will lead to a shift in Taksim centred traffic towards this region, if improvements are made to the region. With the newly arranged Taksim Square, the redirection of traffic underground partially creates a new urban transportation demand. In the transportation plans, it is forecasted that there will be new, increased traffic densities due to functionality changes; that Kabataş, which has very limited space, will be converted into a transfer area for sea, land and rail transportation systems, including interprovincial transportation, creating a massive fill area on the Kabataş coast for this transfer area; that there will be a widening of the Meclis'i Mebusan Street at the Dolmabahçe part; that there will be different road widths established on Suraselviler Street; that the multi-storey car park will not be integrated with public transportation; and that there will be private vehicle-oriented regulations at historical centres. If these plans are realized they will create new problems related to maintaining the historic fabric of the site.

"Touristification" of cultural heritage: Within the planning hierarchy, upper-scale plans direct low-scale plan decisions. The 1/100.000 scale Istanbul Metropolitan Plan serves as the upper-scale plan and therefore as the basis of the 1/5000 scale Beyoğlu Urban Site Conservation Master Plan. In the Istanbul Metropolitan Plan Report, a traditional centre designation is made for the Beyoğlu district, and focus is placed on the sectors expected to undergo development due to the port effect. The report includes the following explanation on this issue: "The Beyoğlu district is a focal point for cultural-arts services and the entertainment industry and also presents a traditional central area that interacts with Eminönü. Financial institutions, insurance services, and transportation and maritime services providing services to companies in the port are present in the district due to the 
port.” [16]. The report also states that Beyoğlu is the centre of festival-oriented space uses, which are important for cultural industries. As understood from this explanation, in the area under planning, which includes the Central Business District (CBD) and the Integration Zone, there will be cultural industries, facilities and residential units, as well as trade, service and tourism functions. However, there is no description of "cultural industries" in the report for the conservation master plans and there are no approaches, models or provisions for the development of culture industries, which should be determined in detail. Moreover, tourism development has been related to trade and service development in the conservation master plans, but there are insufficient explanations and suggestions on cultural development. It can be understood that the cultural tourism concept is only related to businessmen and high-income tourists [15]. In the conservation master plans, tourism developments have been linked to the development of the trade and service sectors, and sufficient explanations and suggestions about cultural studies have not been made. Although it is required, necessary precautions against total "touristification" of the historical region, alienation of citizen life, and displacement effects have not been taken in the Beyoğlu Urban Site Conservation Master Plan.

\section{CONCLUSIONS}

Urban sites as a whole include registered buildings, the urban fabric, the city skyline, public open spaces, as well as urban, natural, and cultural landscape values. They are areas with architectural, local, historical, aesthetic, and artistic characteristics, and as such, incorporate various cultural and natural environmental elements (buildings, gardens, vegetation coverings, settlement features, walls) which, taken collectively, have more value than their individual values alone, as a result of their coexistence. The coexistence of cultural and environmental elements brings more value to these elements than they otherwise would if each individual element were isolated. The clustering of many aspects of cultural heritage at one location creates significant opportunities. Beyoğlu's outstanding universal value is proportional to its contribution to the tangible and intangible heritage of Istanbul. With its civil architecture and monumental structures, Beyoğlu boasts a wide array of social and cultural values, such as literature, traditions, beliefs, and legends, passed down from generation to generation and secured in the collective social memory, performing arts, such as dance, theatre or traditional music, social events, such as rituals or festivals, and skills and knowledge concerning traditional production. Cultural heritage conservation approaches have evolved from being structure-oriented to holistic-oriented, where the focus is on conservation of urban fabrics. Today, cultural heritage conservation projects are planned in terms of economic, social, environmental, political and physical dimensions. In Turkey, the preparation of conservation master plans concerning urban sites and the editing of the report are regulated by specific statutes. The 1/5000 scale conservation master plans are plans that include strategies for generating employment and added value by improving the social and economic situations of households and businesses operating in the area under question; structural restrictions, which include protection principles and conditions of use for sanitation, renovation areas and projects; application stages and programs; an open space system; pedestrian circulation and vehicle transportation, design principles governing infrastructure facilities, densities and parcel designs; participatory field management models that are in accordance with local ownership and application funding principles; as well as plans, objectives, tools, strategies and planning decisions. However, a structureoriented conservation approach concerning the physical space was predominantly adopted in the conservation master plan for the urban site areas in Beyoğlu. Moreover, it was discovered that there is no evaluation regarding the financial, economic and social aspects 
of the conservation project in the plan, and it also fails to include the implementation stages and programs specified in the provisions of the regulation for the preparation of conservation master plans, the application funding principles, and the participatory field management models. Given the type of conservation plan in question, the plan report should include the aspects specified in the regulation. A significant part of the current report is related to historical development, yet the following issues, which should be included, are not.

The analytical part of the report gives information related to the historical structure of the district. However, the information pertaining to the solutions for the problems of the current plan and the information required by regulation do not appear in the plan report, as Table 2 shows. Only 3 of the 10 basic headings are specifically addressed in the plan report. It is necessary to completely fulfil the conditions stipulated in the regulation for the preparation of the conservation master plan and the preparation of the plan at the approval stage. In carefully examining the boundaries indicated in the conservation master plans, it was seen that the plan decisions for the Perşembe Bazaar and the Galata port areas, which are in the buffer zone by location, are not taken into consideration in the master plans. The port function, which is among the essential functions of Beyoğlu, will be affected significantly as a result of the urban projects connected with the conservation master plans that are to be implemented in areas such as the Galata port and the Perşembe Bazaar. In the competition for urban land use that has emerged from the ongoing Galataport passenger

Table 2: Beyoğlu urban site conservation master plan evaluation. (Source: Adapted from IBB 2008 by Author.)

\begin{tabular}{|l|c|}
\hline \multicolumn{1}{|c|}{$\begin{array}{c}\text { Issues the conservation master plan should include (according to Law } \\
\text { Number 2863)/Presence in the plan report }\end{array}$} & Review \\
\hline $\begin{array}{l}\text { Strategies to improve the social and economic structure of businesses in the } \\
\text { urban conservation site and to create added-value: Not in the report; there is } \\
\text { only a proposal that these functions should be removed. }\end{array}$ & - \\
\hline $\begin{array}{l}\text { Principles of conservation: Rarely mentioned. Conservation is mostly based } \\
\text { on reclamation decisions. }\end{array}$ & - - \\
\hline Principles of use: Briefly mentioned in the report. & $+/-$ \\
\hline $\begin{array}{l}\text { Construction boundaries: The assessments in the report are not sufficient. For } \\
\text { example, it is not specified how a commercial area that is proprietary and still } \\
\text { selling hardware materials, should be conserved. The requirements for the } \\
\text { physical situation are also unclear. }\end{array}$ & $+/-$ \\
\hline Rehabilitation: Not in the report. & - \\
\hline $\begin{array}{l}\text { Renewal area and projects: Not in the report. Urban renewal sites are } \\
\text { determined by the Council of Ministers. Therefore, the renewal sites and } \\
\text { projects should also be explained in the report. }\end{array}$ & - \\
\hline Implementation stages and projects: Not in the report. & - \\
\hline Financing the implementation: Not in the report. & - \\
\hline Participative administration model: Not in the report. & - \\
\hline $\begin{array}{l}\text { Goals, objectives, strategies, planning decisions: In the report in Section 5.1. } \\
\text { Plan, Goals and Objectives. }\end{array}$ & + \\
\hline
\end{tabular}


port construction project, hotels will replace companies, especially insurance companies and banks, in company-concentrated centres located on Meclis-i Mebusan Street. Moreover, conflicts among stakeholders regarding the conservation of cultural heritage and certain controversial project implementations at approximately 20 different points indicated in the conservation master plan have begun to surface. These projects have a number of problems, not only concerning conservation legislation but also concerning conservation principles published by ICOMOS, and as such, they have escalated the conflict between culture-led tourism and the conservation of cultural heritage. Conservation principles are mentioned in the "Charter for The Conservation of Historic Towns and Urban Areas" accepted by developed western countries [17]. However, the contemporary urban conservation approaches and principles stated in the ICOMOS have not been observed in the Beyoğlu Urban Site Conservation Master Plan and Plan Report. The plan and report are not compatible with the regulation on procedures and principles of conservation master plan and environment regulation project preparation, indication, implementation, control and editing. The main findings from the evaluations conducted on the Beyoğlu conservation master plan are given below: (a) the conservation master plan boundaries do not incorporate other historic areas in the same district; therefore the master plan lacks a holistic planning approach, (b) the decision to reconstruct former historic buildings will result in damages to the use of public space, (c) car-oriented transport decisions will increase vehicle traffic in the historic centre of the city, (d) the existing cultural structure is in the process of "touristification", particularly culture-led tourism development, and cultural functions are being rapidly "commercialized". The results of the study show that the Beyoğlu (Istanbul) Urban Site Conservation Master Plan will have negative effects on tangible and intangible heritage, publicness, the public participation process, culture-led tourism, and culture-led urban regeneration.

\section{REFERENCES}

[1] De Ascaniis, S., Gravari-Barbas, M. \& Cantoni, L., Tourism Management at UNESCO World Heritage Sites, Università della Svizzera italiana, 2018.

[2] Van Zyl, C.J., The role of tourism in the conservation of cultural heritage with particular relevance for South Africa. Doctoral dissertation, University of Stellenbosch: Stellenbosch, 2005.

[3] Sakızlığlu, B., A comparative look at residents' displacement experiences: the cases of Amsterdam and Istanbul. Unpublished $\mathrm{PhD}$ thesis, Urban and Regional Research Center, Utrecht University, 2014.

[4] García-Hernández, M., De la Calle-Vaquero, M. \& Yubero, C., Cultural heritage and urban tourism: historic city centres under pressure. Sustainability, 9(8), p. 1346, 2017. DOI: $10.3390 /$ su9081346.

[5] Nasser, N., Planning for urban heritage places: reconciling conservation, tourism, and sustainable development. Journal of Planning Literature, 17(4), pp. 467-479, 2003. DOI: $10.1177 / 0885412203017004001$.

[6] Richards, G., Cultural Tourism: Global and Local Perspectives, The Haworth Hospitality Press: New York, 2007.

[7] Erbas, A.E., Central Business District Planning and the Sustainable Urban Development Process in Istanbul [in:] Sustainable City VIII, Zubir, S.S., Brebbia, C.A. (eds.). WIT Press, Southampton, UK, 179(12), pp. 69-80, 2014. DOI: 10.2495/SC130061.

[8] Porter, B.W. \& Salazar, N.B., Heritage tourism, conflict, and the public interest: an introduction. International Journal of Heritage Studies, 11(5), pp. 361-370, 2005. 
[9] UNESCO, What is intangible cultural heritage? Online. https://ich.unesco.org/doc/src/01851-EN.pdf. Accessed on: 13 Jul. 2018.

[10] UNESCO, Intangible Cultural Heritage. Online. https://ich.unesco.org/en/lists. Accessed on: 13 Jul. 2018.

[11] Özden, P. \& Turgut, S., Towards a sustainable and tourism-led urban regeneration objective: Eminonu historical city core. WIT Transactions on Ecology and the Environment, 84, 2005.

[12] Uysal, Ü.E. \& Özden, P.P., Cultural Tourism as a tool of Urban Regeneration in Istanbul. WIT Transactions on Ecology and the Environment, 167, pp. 389-400, 2012. DOI: $10.2495 / \mathrm{ST} 110351$.

[13] Cezar, M., 19. Yüzyıl Beyoğlusu, Akbank Yayınları: Istanbul, 1991.

[14] Akın, N., 19. Yüzyılın İkinci Yarısında Galata ve Pera, Literatür Publications, No. 24, İstanbul, 1998.

[15] IBB, 1/5.000 scale Beyoglu Urban Site Conservation Master Plan and Plan Report, Directorate of Planning, Istanbul, 2008.

[16] IBB, 1/100.000 scale İstanbul Metropolitan Plan and Plan Report, IMP, BIMTAS, Istanbul, 2009.

[17] ICOMOS, Charter for the Conservation of Historic Towns and Urban Areas, Online. www.icomos.org/charters/towns_e.pdf. Accessed on: 20 Nov. 2017. 